ISSN 0258-7122

Bangladesh J. Agril. Res. 38(3): 447-453, September 2013

\title{
SPLIT APPLICATION OF INORGANIC FERTILIZERS IN POTATO (Solanum tuberosum L.)-HYBRID MAIZE (Zea mays L.) INTERCROPPING SYSTEM
}

\author{
M. N. ISLAM ${ }^{1}$, M. AKHTERUZZAMAN ${ }^{2}$ AND M. S. ALOM ${ }^{3}$
}

\begin{abstract}
The experiment was conducted at the research field of Agronomy Division, BARI, Joydebpur, Gazipur during the rabi season of 2009-10 and 2010-11 to find out economic fertilizer dose along with time of split application of fertilizers to potato-hybrid maize intercropping system for higher productivity. Six treatment combinations were derived through combining two fertilizer doses $\mathrm{F}_{1}=255-55-140-40-6-2$ and $\mathrm{F}_{2}=320-73-170-50-6-2 \mathrm{~kg} / \mathrm{ha}$ NPKSZnB and three levels of split applications viz., $\mathrm{S}_{1}=1 / 3 \mathrm{~N}$ and full of PKSZnB (basal as broadcast) $+1 / 3 \mathrm{~N}$ top dressed at $30 \mathrm{DAP}$ (days after planting) of potato $+1 / 3 \mathrm{~N}$ top dressed after potato harvest, $\mathrm{S}_{2}=1 / 3 \mathrm{~N} \& 1 / 2$ of $\mathrm{PKSZnB}$ (basal in potato rows) $+1 / 2$ of PKSZnB (basal for maize) $+1 / 3 \mathrm{~N}$ top dressed at $30 \mathrm{DAP}$ of potato $+1 / 3 \mathrm{~N}$ top dressed after potato harvest and $\mathrm{S}_{3}=1 / 4 \mathrm{~N} \& 1 / 2$ of PKSZnB (basal in potato rows) $+1 / 2$ of PKSZnB (basal for maize) $+1 / 4 \mathrm{~N}$ top dressed at 30 DAP of potato $+1 / 4 \mathrm{~N}$ top dressed at $60 \mathrm{DAP}$ of potato to maize rows only $+1 / 4 \mathrm{~N}$ top dressed after potato harvest. Sole crops of hybrid maize and potato with recommended fertilizer dose of 255-55-140-40-6-2 and 135-30-135-15-4-0.5 $\mathrm{kg} / \mathrm{ha}$ NPKSZnB were included for comparison. The highest tuber yield of potato $(24.24 \mathrm{t} / \mathrm{ha})$ and grain yield of maize $(9.48 \mathrm{t} / \mathrm{ha})$ were obtained from respective sole crops with recommended fertilizer management. The highest potato equivalent yield (30.26 t/ha), gross return (Tk. 363120/ha), gross margin (Tk. 258620/ha), and benefit cost ratio (3.47) were obtained from $F_{1} S_{3}$. The results revealed that fertilizer dose of 255-55-140-40-6-2 kg/ha NPKSZnB along with its split application, $1 / 4 \mathrm{~N}$ and $1 / 2$ of PKSZnB (basal in potato rows) $+1 / 2$ of PKSZnB (basal for maize) $+1 / 4 \mathrm{~N}$ top dressed at $30 \mathrm{DAP}$ of potato $+1 / 4 \mathrm{~N}$ top dressed at $60 \mathrm{DAP}$ of potato to maize rows only $+1 / 4 \mathrm{~N}$ top dressed after potato harvest, might be economically profitable for potato hybrid maize intercropping system.
\end{abstract}

Keywords: Split application, inorganic fertilizers, potato-hybrid maize intercropping.

\section{Introduction}

Potato is a high yield potential tuber crop and its potential yield is estimated as 25-35 t/ha in Bangladesh. Conversely, hybrid maize is a high yielding cereal crop and may produce about 8-11 t/ha of grain yield. Both the crops have diversified uses. Potato and maize may be grown as intercrop as they have different growth

\footnotetext{
${ }^{1-3}$ Principal Scientific Officer, Agronomy Division, Bangladesh Agricultural Research Institute (BARI), Gazipur 1701, Bangladesh.
} 
habits, growth duration, and demand for growth resources (Chand et al., 2001). Greater productivity in intercropping system is commonly achieved by minimizing inter-specific competition and maximizing complementary use of growth resources (Ifenkwe et al., 1989). Inter-specific competition may be minimized by shifting the period of peak demand for growth resources through changing the time of sowing of the component crops (Islam et al., 2004). Sowing of potato and maize at different times is important agronomic approaches in intercropping system to minimize inter specific competition and it has been determined (Anon., 2006). Fertilizer management is another important agronomic management practice for increasing system productivity of potatohybrid maize intercropping system (Akhteruzzaman et al., 2008). As life cycle of potato and hybrid maize is different, so the fertilizer requirement and its management practices also varied. Moreover, split application of fertilizer to component crops increased total productivity as well as fertilizer use efficiency through reducing leaching loss of nutrients (Gill and Ahmed, 1985; Ceretta et al., 2002). But information regarding split application of fertilizers to potato hybrid maize intercropping system is meagre. Therefore, the present experiment was undertaken to find out economic fertilizer dose along with time of split application of fertilizers to potato-hybrid maize intercropping system for higher productivity.

\section{Materials and Method}

The experiment was conducted at the research field of Agronomy Division, BARI, Joydebpur, Gazipur during two consecutive rabi seasons of 2009-10 and 2010-11. The soil of the experimental field was silty clay loam in texture with $\mathrm{pH}$ 5.8 belonging to Chhiata series under AEZ-28. The soil was low in organic matter (1.2\%) and deficient in total $\mathrm{N}(0.07 \%)$, available $\mathrm{P}(13 \mathrm{ppm})$, exchangeable K $(0.15 \mathrm{meq} / 100 \mathrm{~g}$ soil $)$, available $\mathrm{S}(12 \mathrm{ppm})$ and available B $(0.12 \mathrm{ppm})$. The crop received total rainfall of 201 and $226 \mathrm{~mm}$ during crop growing period in 2009-10 and 2010-11, respectively. The monthly mean maximum and minimum air temperature were $29.0{ }^{\circ} \mathrm{C}$ and $17.8{ }^{\circ} \mathrm{C}$, respectively during 2009-10 while $28.7^{\circ} \mathrm{C}$ and $17.6^{\circ} \mathrm{C}$, respectively in 2010-11. Six treatment combinations were derived through combining two fertilizer doses $\left(\mathrm{F}_{1}=255-55\right.$ 140-40-6-2 (recommended fertilizer for maize) and $F_{2}=320-73-170-50-6-2 \mathrm{~kg} / \mathrm{ha}$ NPKSZnB) and three levels of split applications viz. $S_{1}=1 / 3 \mathrm{~N}$ and full of PKSZnB (basal as broadcast) $+1 / 3 \mathrm{~N}$ top dressed at 30 DAP of potato $+1 / 3 \mathrm{~N}$ top dressed after potato harvest, $\mathrm{S}_{2}=1 / 3 \mathrm{~N}$ and $1 / 2$ of PKSZnB (basal in potato rows) $+1 / 2$ of PKSZnB (basal for maize) $+1 / 3 \mathrm{~N}$ top dressed at 30 DAP of potato $+1 / 3 \mathrm{~N}$ top dressed after potato harvest and $S_{3}=1 / 4 \mathrm{~N} \& 1 / 2$ of PKSZnB (basal in potato rows) $+1 / 2$ of PKSZnB (basal for maize) $+1 / 4 \mathrm{~N}$ top dressed at 30 DAP of potato $+1 / 4 \mathrm{~N}$ top dressed at $60 \mathrm{DAP}$ of potato to maize rows only $+1 / 4 \mathrm{~N}$ top dressed after potato harvest. Sole crops of hybrid maize and potato with 
recommended fertilizer dose of 255-55-140-40-6-2 and 135-30-135-15-4-0.5 $\mathrm{kg} / \mathrm{ha}$ NPKSZnB were included for comparison. The experiment was laid out in a randomized complete block (RCB) design with 3 replications. The unit plot size was $3 \mathrm{~m} \times 3 \mathrm{~m}$. Diamant variety of potato and BARI Hybrid Maize-5 variety of hybrid maize were used in this study. Potato was planted on 20 November 2009 and 23 November 2010 maintaining $75 \mathrm{~cm}$ x $20 \mathrm{~cm}$ spacing. Maize was sown on 10 December 2009 and 13 December 2010 (20 days after potato planting) in between two potato rows with a seed to seed distance of $20 \mathrm{~cm}$. Sole potato and sole maize were sown with $60 \mathrm{~cm}$ x $25 \mathrm{~cm}(66,666$ plants/ha) and $75 \mathrm{~cm}$ x $20 \mathrm{~cm}$ (66,666 plants/ha), respectively. In sole potato, $1 / 2$ of $\mathrm{N}$ and full amount of PKSZnB were applied as basal in the form of urea, triple super phosphate, muriate of potash, gypsum, zinc sulphate, and boric acid, respectively. The remaining $\mathrm{N}$ was top dressed at 30 days after potato planting followed by irrigation. In sole maize, $1 / 3$ of $\mathrm{N}$ and full amount of PKSZnB were applied as basal and rest $\mathrm{N}$ was top dressed in two equal splits at 30 and $60 \mathrm{DAE}$ (days after emergence) of maize. In intercropping systems, fertilizers were applied as per treatments. A light irrigation was given after potato sowing for uniform emergence. Earthing up of potato, sowing of maize and $1^{\text {st }}$ top dressing was done on the same day followed by irrigation. Intercultural operations were done as and when required. Potato was harvested on 23 February 2010 (95DAS) and 26 February 2011 (95 DAS). Maize was harvested on 02 May 2010 (143 DAS) and 05 May 2011 (143 DAS). Data on yield and other parameters of both the crops were recorded at the time of harvest. Plant population data for potato and maize were taken from randomly selected three places in each plot and yield components were taken from 10 plants in both the years. Yields of both the crops were taken from whole plot. Potato equivalent yield (PEY) was computed by converting yield of intercrops on the basis of prevailing market price of individual crop following the formula of Bandyopadhyay (1984) as given below:

$P E Y=$ Yip $+\frac{\text { Yim } x P m}{P p}$ Where, Yip $=$ Yield of intercrop potato, Yim $=$ Yield of intercrop maize, $\mathrm{Pp}=$ Price of potato, $\mathrm{Pm}=$ Price of maize

Benefit-cost analysis was also done. The data of yield and yield attributes of the experiment for two consecutive years showed similar trend. So, the collected data were pooled and means were adjudged by LSD test at 5\% level of significance.

\section{Results and Discussion}

\section{Effect on potato}

Yield and yield components of potato in sole crop with recommended fertilizer management did not differ significantly from those in intercropping systems 
under different dose and split application of fertilizers (Table 1). Fertilizer dose and its split application might fulfill the requirement of potato crop in potatohybrid maize intercropping system and it might be the reason of similar yield and yield components of potato in sole and intercropping system. This result is in agreement with the findings of Akhteruzzaman et al. (2008). However, the yield of potato in different treatments varied from 20.48 to $24.24 \mathrm{t} / \mathrm{ha}$ where 3.47 to $15.51 \%$ yield reduction was recorded in intercropping systems than sole potato.

Table 1. Yield and yield components of potato in potato-hybrid maize intercropping under different dose and split application of fertilizers (pooled data of two years).

\begin{tabular}{|c|c|c|c|c|c|}
\hline Treatments & $\begin{array}{c}\text { Hills } / \mathrm{m}^{2} \\
\text { (no.) }\end{array}$ & $\begin{array}{c}\text { Tuber/hill } \\
\text { (no.) }\end{array}$ & $\begin{array}{l}\text { Tuber wt/ hill } \\
(\mathrm{g})\end{array}$ & $\begin{array}{c}\text { Single tuber } \\
\text { wt }(\mathrm{g})\end{array}$ & $\begin{array}{c}\text { Tuber yield } \\
\text { (t/ha) }\end{array}$ \\
\hline$\overline{F_{1} S_{1}}$ & 6.5 & 8.8 & 347 & 39.43 & 22.55 \\
\hline $\mathrm{F}_{1} \mathrm{~S}_{2}$ & 6.4 & 9.0 & 350 & 38.89 & 22.90 \\
\hline $\mathrm{F}_{1} \mathrm{~S}_{3}$ & 6.5 & 9.3 & 360 & 38.71 & 23.40 \\
\hline $\mathrm{F}_{2} \mathrm{~S}_{1}$ & 6.5 & 9.1 & 340 & 37.36 & 22.10 \\
\hline $\mathrm{F}_{2} \mathrm{~S}_{2}$ & 6.4 & 8.7 & 320 & 36.78 & 20.48 \\
\hline $\mathrm{F}_{2} \mathrm{~S}_{3}$ & 6.5 & 8.9 & 320 & 35.96 & 20.80 \\
\hline Sole potato & 6.5 & 9.5 & 373 & 39.26 & 24.24 \\
\hline $\operatorname{LSD}_{(0.05)}$ & NS & NS & NS & NS & NS \\
\hline CV (\%) & 9.2 & 10.1 & 9.8 & 7.6 & 12.0 \\
\hline
\end{tabular}

$\mathrm{NS}=$ Not significant

$\mathrm{F}_{1}=255-55-140-40-6-2 \mathrm{~kg} / \mathrm{ha}$ NPKSZnB and $\mathrm{F}_{2}=320-73-170-50-6-2 \mathrm{~kg} / \mathrm{ha}$ NPKSZnB

$\mathrm{S}_{1}=1 / 3 \mathrm{~N} \&$ full of PKSZnB (basal as broadcast) $+1 / 3 \mathrm{~N}$ top dressed at $30 \mathrm{DAP}$ of potato $+1 / 3 \mathrm{~N}$ top dressed after potato harvest,

$\mathrm{S}_{2}=1 / 3 \mathrm{~N} \& 1 / 2$ of PKSZnB (basal in potato rows) $+1 / 2$ of PKSZnB (basal for maize) $+1 / 3$ $\mathrm{N}$ top dressed at $30 \mathrm{DAP}$ of potato $+1 / 3 \mathrm{~N}$ top dressed after potato harvest and

$\mathrm{S}_{3}=1 / 4 \mathrm{~N} \& 1 / 2$ of PKSZnB (basal in potato rows) $+1 / 2$ of PKSZnB (basal for maize) $+1 / 4 \mathrm{~N}$ top dressed at $30 \mathrm{DAP}$ of potato $+1 / 4 \mathrm{~N}$ top dressed at $60 \mathrm{DAP}$ of potato to maize rows only $+1 / 4 \mathrm{~N}$ top dressed after potato harvest

\section{Effect on maize}

Number of cobs per $\mathrm{m}^{2}$, grains per cob, 1000-grain weight, and grain yield of hybrid maize in potato hybrid maize intercropping systems under different fertilizer managements varied significantly from those of hybrid maize in sole crop with recommended fertilizer management (Table 2). The difference in number of cobs per $\mathrm{m}^{2}$ of maize was attributed mainly to the variation in planting system in inter and sole cropping. Significantly the highest cobs/plant was recorded from sole maize. The maximum number of grains/cob was recorded in sole maize with recommended fertilizer management (467) which was at par with those in $F_{2} S_{3}$ (463), $F_{1} S_{3}(461), F_{2} S_{2}$ (438) and $F_{1} S_{2}$ (434). Thousand-grain 
weight was found maximum in sole maize with recommended fertilizer management (284.2 g) which was statistically similar with $\mathrm{F}_{2} \mathrm{~S}_{3}(283.7 \mathrm{~g}), \mathrm{F}_{2} \mathrm{~S}_{2}$ $(273.5 \mathrm{~g})$, and $\mathrm{F}_{1} \mathrm{~S}_{3}(272.6 \mathrm{~g})$. The identical values of grains/cob and 1000-grain weight of maize in aforesaid treatments were found might be owing to basal application of fertilizer to maize. Grain yield was the highest in sole maize with recommended fertilizer management $(9.48 \mathrm{t} / \mathrm{ha})$ and it was $21-59 \%$ higher than those in potato hybrid maize intercropping under different fertilizer managements practices (Table 2). The higher grain yield of maize in sole crop was attributed to the cumulative effect of higher yield components. This result was supported by the findings of Chand et al. (2001). Irrespective of fertilizer doses $\left(F_{1}\right.$ or $\left.F_{2}\right)$ higher grain yields of maize were recorded in $S_{2}$ and $S_{3}$ treatments where fertilizer splited. The higher grain yields of intercropped maize in $S_{2}$ and $S_{3}$ treatments might be due to higher yield components. Ceretta et al. (2002) also reported higher grain yield of corn due to split application of fertilizer.

Table 2. Grain yield and yield components of maize in potato-hybrid maize intercropping under different dose and split application of fertilizers (pooled data of two years).

\begin{tabular}{l|c|c|c|c|c}
\hline Treatments & $\begin{array}{c}\text { Cobs/m } \\
\text { (no.) }\end{array}$ & $\begin{array}{c}\text { Cob/plant } \\
\text { (no.) }\end{array}$ & $\begin{array}{c}\text { Grains/cob } \\
\text { (no.) }\end{array}$ & $\begin{array}{c}\text { 1000-grain } \\
\text { wt (g) }\end{array}$ & $\begin{array}{c}\text { Grain yield } \\
\text { (t/ha) }\end{array}$ \\
\hline $\mathrm{F}_{1} \mathrm{~S}_{1}$ & 5.1 & 1.01 & 328 & 232.3 & 3.92 \\
$\mathrm{~F}_{1} \mathrm{~S}_{2}$ & 5.2 & 1.03 & 434 & 263.4 & 6.12 \\
$\mathrm{~F}_{1} \mathrm{~S}_{3}$ & 5.3 & 1.03 & 461 & 272.6 & 6.86 \\
$\mathrm{~F}_{2} \mathrm{~S}_{1}$ & 5.2 & 1.01 & 331 & 238.3 & 4.14 \\
$\mathrm{~F}_{2} \mathrm{~S}_{2}$ & 5.2 & 1.04 & 438 & 273.5 & 6.48 \\
$\mathrm{~F}_{2} \mathrm{~S}_{3}$ & 5.4 & 1.05 & 463 & 283.7 & 7.45 \\
$\mathrm{Sole} \mathrm{maize}$ & 6.8 & 1.05 & 467 & 284.2 & 9.48 \\
\hline $\mathrm{LSD}$ & 0.97 & $\mathrm{NS}$ & 37.9 & 20.2 & 1.49 \\
$\mathrm{CV}(\%)$ & 10.0 & 2.8 & 5.1 & 4.3 & 13.2 \\
\hline
\end{tabular}

$\mathrm{F}_{1}=255-55-140-40-6-2 \mathrm{~kg} / \mathrm{ha}$ NPKSZnB and $\mathrm{F}_{2}=320-73-170-50-6-2 \mathrm{~kg} / \mathrm{ha}$ NPKSZnB

$\mathrm{S}_{1}=1 / 3 \mathrm{~N} \&$ full of PKSZnB (basal as broadcast) $+1 / 3 \mathrm{~N}$ top dressed at $30 \mathrm{DAP}$ of potato $+1 / 3 \mathrm{~N}$ top dressed after potato harvest,

$\mathrm{S}_{2}=1 / 3 \mathrm{~N} \& 1 / 2$ of PKSZnB (basal in potato rows) $+1 / 2$ of PKSZnB (basal for maize) $+1 / 3$ $\mathrm{N}$ top dressed at $30 \mathrm{DAP}$ of potato $+1 / 3 \mathrm{~N}$ top dressed after potato harvest and

$\mathrm{S}_{3}=1 / 4 \mathrm{~N} \& 1 / 2$ of PKSZnB (basal in potato rows) $+1 / 2$ of PKSZnB (basal for maize) $+1 / 4 \mathrm{~N}$ top dressed at $30 \mathrm{DAP}$ of potato $+1 / 4 \mathrm{~N}$ top dressed at $60 \mathrm{DAP}$ of potato to maize rows only $+1 / 4 \mathrm{~N}$ top dressed after potato harvest.

\section{System productivity}

Total yield in terms of potato equivalent yields (PEY) in all treatment combinations were higher (26.47-30.26 t/ha) than either of the sole crop with 
recommended fertilizer managements (Table 3). The highest PEY (30.26 t/ha) was obtained from $F_{1} S_{3}$, which was close to that from $F_{1} S_{2}(29.02 t / h a)$. PEY was the lowest $(26.47 \mathrm{t} / \mathrm{ha})$ in $\mathrm{F}_{1} \mathrm{~S}_{1}$, which was very close to that in $\mathrm{F}_{2} \mathrm{~S}_{1}(26.24 \mathrm{t} / \mathrm{ha})$. The results indicate that PEYs vary mainly due to variation in yields of component crops under different management practices. Gross return increased with the increase of PEY and the highest gross return was recorded in $\mathrm{F}_{1} \mathrm{~S}_{3}$ (Tk. $363120 /$ ha), which was close to that in $\mathrm{F}_{1} \mathrm{~S}_{2}$ (Tk. 348240/ha). The cost of production mainly increased with the increase of fertilizer cost as well as involvement of more labour for management practices. The highest gross margin (Tk. 258620/ha) was obtained from $\mathrm{F}_{1} \mathrm{~S}_{3}$ due to higher PEY and gross return though cost of production was much higher than sole potato or sole maize but among the intercropping systems the cost was reasonable. Gross return and gross margin reflected the benefit cost ratio (BCR) in the treatments. As a result, higher BCR was recorded in $F_{1} S_{3}$ (3.47) which was followed by that in $F_{1} S_{2}$ (3.35). Akhteruzzaman et al. (2008) also obtained more benefit from intercropping due to judicious application of fertilizers.

Table 3. Potato equivalent yield (PEY) and benefit cost analysis of potato-hybrid maize intercropping under different dose and split application of fertilizers (pooled data of two years).

\begin{tabular}{l|c|c|c|c|c}
\hline Treatments & $\begin{array}{c}\text { PEY } \\
\text { (t/ha) }\end{array}$ & $\begin{array}{c}\text { Gross return } \\
\text { (Tk./ha) }\end{array}$ & $\begin{array}{c}\text { Cost of } \\
\text { production } \\
\text { (Tk./ha) }\end{array}$ & $\begin{array}{c}\text { Gross margin } \\
\text { (Tk./ha) }\end{array}$ & $\begin{array}{c}\text { Benefit cost } \\
\text { ratio }\end{array}$ \\
\hline $\mathrm{F}_{1} \mathrm{~S}_{1}$ & 26.47 & 317640 & 103800 & 213840 & 3.06 \\
$\mathrm{~F}_{1} \mathrm{~S}_{2}$ & 29.02 & 348240 & 104000 & 244240 & 3.35 \\
$\mathrm{~F}_{1} \mathrm{~S}_{3}$ & 30.26 & 363120 & 104500 & 258620 & 3.47 \\
$\mathrm{~F}_{2} \mathrm{~S}_{1}$ & 26.24 & 314880 & 108000 & 206880 & 2.92 \\
$\mathrm{~F}_{2} \mathrm{~S}_{2}$ & 26.96 & 323520 & 108500 & 215020 & 2.98 \\
$\mathrm{~F}_{2} \mathrm{~S}_{3}$ & 28.25 & 339000 & 109000 & 230000 & 3.11 \\
Sole maize & 9.48 & 113760 & 44500 & 69260 & 2.56 \\
Sole potato & 24.24 & 290880 & 97000 & 193880 & 3.00 \\
\hline
\end{tabular}

Price (Tk./kg): Maize 12/- and potato 12/-

$F_{1}=255-55-140-40-6-2 \mathrm{~kg} / \mathrm{ha} \mathrm{NPKSZnB}$ and $\mathrm{F}_{2}=320-73-170-50-6-2 \mathrm{~kg} / \mathrm{ha}$ NPKSZnB

$\mathrm{S}_{1}=1 / 3 \mathrm{~N} \&$ full of PKSZnB (basal as broadcast) $+1 / 3 \mathrm{~N}$ top dressed at $30 \mathrm{DAP}$ of potato $+1 / 3 \mathrm{~N}$ top dressed after potato harvest,

$\mathrm{S}_{2}=1 / 3 \mathrm{~N} \& 1 / 2$ of PKSZnB (basal in potato rows) $+1 / 2$ of PKSZnB (basal for maize) $+1 / 3$ $\mathrm{N}$ top dressed at $30 \mathrm{DAP}$ of potato $+1 / 3 \mathrm{~N}$ top dressed after potato harvest and

$\mathrm{S}_{3}=1 / 4 \mathrm{~N} \& 1 / 2$ of PKSZnB (basal in potato rows) $+1 / 2$ of PKSZnB (basal for maize) $+1 / 4 \mathrm{~N}$ top dressed at $30 \mathrm{DAP}$ of potato $+1 / 4 \mathrm{~N}$ top dressed at $60 \mathrm{DAP}$ of potato to maize rows only $+1 / 4 \mathrm{~N}$ top dressed after potato harvest. 
The results revealed that fertilizer dose of 255-55-140-40-6-2 kg/ha NPKSZnB along with its split application $(1 / 4 \mathrm{~N} \& 1 / 2$ of PKSZnB (basal in potato rows) $+1 / 2$ of PKSZnB (basal for maize) $+1 / 4 \mathrm{~N}$ top dressed at 30 DAP of potato $+1 / 4 \mathrm{~N}$ top dressed at 60 DAP of potato to maize rows only $+1 / 4 \mathrm{~N}$ top dressed after potato harvest) might be economically profitable for potato hybrid maize intercropping system.

\section{References}

Akhteruzzaman, M., M. N. Islam, B. L. Nag and M. T. Rahman. 2008. Productivity of potato-hybrid maize relay cropping under different fertilizer levels. Eco-friendly Agril. J. 1(5): 300-303.

Anonymous. 2006. Relaying of hybrid maize with potato across environment. Annual Research Report of 2005-06. On-Farm Research Division, BARI, Joydebpur, Gazipur. Pp. 303-305.

Bandyopadhyay, S. N. 1984. Nitrogen and water relations in grain sorghum-legume intercropping systems. Ph. D. Dissertation, Indian Agricultural Research Institute, New Delhi.

Ceretta, C. A., C. J. Basso, J. Diekow, C. Aita, P. S. Pavinato, F. C. B. Vieira, E. R. O. Vendrusculo. 2002. Nitrogen fertilizer split-application for corn in no-till succession to black oats. Scientia Agricola 59(3): 549-554.

Chand, S. P., H. C. Lee, D. H. Scarisbrick, F. E. Tollervey. 2001. Potato (Solanum tuberosum) intercropped with maize (Zea mays) in the Eastern Hills of Nepal. Japanese Journal of Tropical Agriculture 45(3): 167-175.

Gill, M.A. and A. Ahmad. 1985. Effect of split application of nitrogenous fertilizer on the yield and yield components of wheat. Pakistan J. Agric. Res. 6(2): 86-88.

Ifenkwe, O. P., S. O. Odurkwe, J.C. Okonkwo and H.B. Nwokocha. 1989. Effect of maize and potato on tuber and grain yields, net income and land equivalent ratios in potato/maize intercropping. Tropical Agriculture 25: 73-82.

Islam, M. N., M. M. Haque and A. Hamid. 2004. Productivity and competitive interference in maize + bushbean intercropping system in different sowing dates. Bangladesh J. Agril. Res. 29(2): 193-201. 